\title{
KEPEMIMPINAN KEPALA DESA DALAM MEWUJUDKAN DESA MANDIRI DI DESA BOJONGMALAKA KECAMATAN BALEENDAH KABUPATEN BANDUNG
}

\author{
Chintiya Citra Purnama ${ }^{1}$, Dadan Kurnia ${ }^{2}$, Arlan Siddha ${ }^{3}$ \\ 1,2,3Jurusan Ilmu Pemerintahan, Fakultas Ilmu Sosial dan Ilmu Politik, \\ Universitas Jenderal Achmad Yani, Indonesia
}

\begin{abstract}
ABSTRAK
Penelitian ini berjudul "Kepemimpinan Kepala Desa Dalam Mewujudkan Desa Mandiri di Desa Bojongmalaka Kecamatan Baleendah Kabupaten Bandung" penelitian ini dilatarbelakangi dengan melihat kondisi Desa Bojongmalaka yang dipilih sebagai terbaik di Kecamatan Baleendah Kabupaten Bandung sehingga desa ini akan mewujudkan desa mandiri.Metodologi penelitian yang digunakan adalah metode penelitian deskriptif dengan pendekatan kualitatif, dengan maksud memusatkan perhatian terhadap fenomena dan masalah yang terjadi pada saat penelitian dilakukan. Data diperoleh dari hasil observasi, dokumentasi dan wawancara dengan informan kunci sebagai data primer. Informan kunci ditentukan berdasarkan beberapa kriteria yakni, setidaknya ada 3 narasumber yang dijadikan objek penelitian yakni Kepala Desa, Sekretaris Desa, dan Ketua Badan Permusyawaratan Desa (BPD). Data diolah dengan cara reduksi data, kategorisasi data, sintesisasi dan menyusun hipotesis kerja sebagai langkah terkahir pada proses penyusunan data. Hasil penelitian menunjukan bahwa kepemimpinan kepala desa dalam mewujudkan desa mandiri di desa bojongmalaka kecamatan baleendah kabupaten bandung itu sudah tercapai dengan baik dan maksimal. Namun program yang dilakukan masih dalam tahap proses untuk mewujudkan desa nya menjadi menjadi desa mandiri. Konsep dan program desa sedang dilakukan oleh kepala desa bersama perangkat desanya agar mendapatkan hasil yang lebih maksimal lagi sehingga desa ini bisa dikatakan desa mandiri.
\end{abstract}

Kata Kunci : kepemimpinan, kepala desa, desa mandiri

\begin{abstract}
The research entitled "Village Head Leadership in Creating Independent Villages in Bojongmalaka Village, Baleendah District, Bandung Regency" This research is motivated by looking at the condition of Bojongmalaka Village which was chosen as the best in Baleendah District, Bandung Regency so that this village will create an independent village.The research methodology used is descriptive research method with a qualitative approach, with the intention of focusing on the phenomena and problems that occur at the time the research was conducted. Data obtained from observations, documentation and interviews with key informants as primary data. Key informants were determined based on several criteria, at least 3 sources were used as research objects, namely the Village Head, Village Secretary, and the Head
\end{abstract}


of the Village Consultative Body (BPD). The data is processed by means of data reduction, data categorization, synthesization and formulation of working hypotheses as the last step in the data compilation process.The results showed that the leadership of the village head in realizing an independent village in the village of Bojongmalaka, Baleendah District, Bandung Regency has been achieved well and optimally. However, the program being carried out is still in the process of turning the village into an independent village. The village head and village officials are working on the concept and program of the village in order to get maximum results so that this village can be said to be an independent village.

Keywords: leadership, village head, independent village

\section{PENDAHULUAN}

Menurut Undang-Undang Nomor 23 Tahun 2014 Pasal 1 ayat (43) bahwa "Desa adalah desa dan desa adat atau yang disebut dengan nama lain, selanjutnya disebut Desa, adalah kesatuan masyarakat hukum yang memiliki batas wilayah yang berwenang untuk mengatur dan mengurus Urusan Pemerintahan, kepentingan masyarakat setempat berdasarkan prakarsa masyarakat, hak asal usul, dan/atau hak tradisional yang diakui dan dihormati dalam sistem pemerintahan Negara Kesatuan Republik Indonesia".

Secara umum, UU Desa meletakkan desa dalam posisi selayaknya, yakni sebagai kesatuan masyarakat hukum khas Indonesia yang keberadaannya mendahului Negara Modern Indonesia. Selain itu juga pengakuan atas kewenangan lokal berskala desa yang memberikan kekuasaan bagi desa untuk menyelenggarakan pembangunan desa secara mandiri. Dalam istilah lain, Desa Mandiri bertumpu pada Trisakti Desa yaitu karsa, karya, sembada. Jika Trisakti Desa dapat dicapai maka desa itu disebut sebagai desa berdikari, karsa, karya, sembada. Jadi yang dimaksud dengan desa mandiri adalah desa yang dapat memenuhi kebutuhannya sendiri tanpa tergantung dari bantuan pemerintah, kalau ada bantuan sifatnya hanya stimulant atau perangsang. Pengembangan yang akan dilakukan pada desa mandiri adalah pengembangan potensi ekonomi, sosial, dan budaya di desa, Pengembangan kemandirian, dan kewirausahaan di desa, Pengembangan kualitas sumber daya manusia dan 
penguatan kelembagaan masyarakat desa, serta pengembangan jejaring dan kemitraan.

Salah satu desa yang akan menuju desa mandiri yaitu Desa Bojongmalaka Kecamatan Baleendah Kabupaten Bandung. Bisa kita lihat pada bulan april 2017 yang lalu Kepala Desa Bojongmalaka Jajang Junaedi, mengatakan ia merasa bangga menyusul ditetapkannya Desa Bojongmalaka sebagai salah satu desa terbaik di Kecamatan Baleendah dan diikutsertakan dalam lomba desa di Kabupaten Bandung. Menurut Jajang, salah satu yang menonjol di desa yang memiliki 17 RW dengan 106 RT dan jumlah Kepala Keluarga sebanyak 23.242 jiwa itu, yakni begitu bersemangatnya masyarakat dalam menyukseskan pembangunan di kawasan itu. Salah satunya yaitu dengan adanya pembangunan jalan sepanjang 1700 meter dengan melihat kondisi masyarakat yang harmonis menjadikan Desa Bojongmalaka genah merenah, dan tumaninah. jadi peran Kepala Desa merupakan salah satu aspek yang menonjol dan berpengaruh terhadap keberhasilan pembangunan desa.

(Sutarno, 2017 http://jabaraekspres.com/Bojongmalaka-Bidik-DesaMandiri/,24 Desember 2017).

Ada beberapa penunjang bahwa Desa Bojongmalaka ini menjadi salah satu desa terbaik ditingkat Kecamatan Baleendah yang akan menuju desa mandiri diantaranya yaitu :

1. Pembuatan RPJMDes ini dibuat sebagai patokan desa untuk membangun kalau desa tidak mempunyai RPJMDes bagaimana desa bisa membangun karena tidak ada arahan/pegangan .

2. Pembenahan administrasi dimana dulu itu dalam hal administrasinya tidak tertata dengan baik namun sekarang terkelola dengan baik secara konvensional maupun digital.

3. Revolusi pelayanan desa dimana dulu revolusi pelayanan desa itu dari jam 9 sampai jam 12 siang namun sekarang revolusi pelayanan disamakan dengan aturan ASN (perangkat daerah) dengan menyediakan standart pelayanan Kabupaten sesuai dengan Peraturan Bupati. 
4. Inovasi desa adalah bentuk karya desa yang bisa diberikan dan bisa dimanfaatkan oleh masyarakat salah satunya yaitu selain menjadi desa terbaik di Kecamatan, desa ini juga berinovasi dibidang teknologi pengelolaan sampah hingga tingkat nasional di Jawa Barat.

Peneliti memiliki ketertarikan dalam melakukan penelitian ini dimana peneliti merasa bahwa pembahasan mengenai Kepemimpinan Kepala Desa Dalam Mewujudkan Desa Mandiri Di Desa Bojongmalaka Kecamatan Baleendah Kabupaten Bandung merupakan pembahasan yang perlu diperdalam kajiannya. Selain itu peneliti juga ingin mengetahui bagaimana Teknik Kepemimpinan Kepala Desa Dalam Mewujudkan Desa Mandiri Di Desa Bojongmalaka Kecamatan Baleendah Kabupaten Bandung. Berdasarkan latar belakang tersebut, peneliti bermaksud untuk melakukan penelitian dengan judul "Kepemimpinan Kepala Desa Dalam Mewujudkan Desa Mandiri Di Desa Bojongmalaka Kecamatan Baleendah Kabupaten Bandung”.

\section{METODE PENELITIAN}

Dalam penelitian ini, metodologi penelitian yang digunakan adalah metode penelitian deskriptif dengan pendekatan kualitatif, dengan maksud memusatkan perhatian terhadap fenomena dan masalah yang terjadi pada saat peneilitian dilakukan. Dalam penelitian ini peneliti mencocokkan antara realita empiris dengan teori yang berlaku dengan menggunakan metode deskriptif. Menurut Kirk dkk (dalam Moleong, 2010:4) yang dimaksud dengan penelitian kualitatif adalah "tradisi tertentu dalam ilmu pengetahuan sosial yang secara fundamental bergantung dari pengamatan pada manusia baik dalam kawasannya maupun dalam peristilahannya”. Dalam penelitian ini peneliti meneliti beberapa obyek diantaranya di lingkungan Desa Bojongmalaka baik Kepala Desa, Sekretaris Desa, Badan Permusyawaratan Desa (BPD) juga masyarakat di daerah Desa Bojongmalaka, serta kondisi alamiah di beberapa obyek lingkungan 
masyarakat.

desa Bojongmalaka yang dapat mendukung peneliti dalam mendapatkan data yang valid.

Moleong (Moleong, 2010:97) mendefinisikan bahwa informan penelitian adalah "orang yang dimanfaatkan untuk memberikan informasi tentang situasi dan kondisi latar belakang penelitian". Informan merupakan orang yang benar-benar mengetahui permasalahan yang akan diteliti. Dalam penelitian ini terdapat 2 informan diantaranya :

1. Informan kunci, yaitu orang-orang yang sangat memahami permasalahan yang diteliti. Adapun yang menjadi informan kunci dalam penelitian ini adalah :

- Kepala Desa

- Sekretaris Desa

2. Informan non kunci, yaitu orang yang dianggap mengetahui permasalahan yang diteliti . Adapun yang menjadi informan non kunci dalam penelitian ini adalah :

- Ketua Badan Permusyawaratan Desa (BPD)

- Warga masyarakat Desa Bojongmalaka Kecamatan Baleendah Kabupaten Bandung.

Data diperoleh dari hasil observasi, dokumentasi dan wawancara dengan informan kunci sebagai data primer. Menurut Sugiyono (2014:225) dalam penelitian kualitatif, "pengumpulan data dilakukan pada natural setting (kondisi yang alamiah), sumber data primer, dan teknik pengumpulan data lebih banyak pada observasi berperan serta (participan observation), wawancara mendalam (in depth interview) dan dokumentasi". Peneliti menggunakan teknik pengumpulan data sebagai berikut. Data diolah dengan cara reduksi data, kategorisasi data, sintesisasi dan menyusun hipotesis kerja sebagai langkah terkahir pada proses penyusunan data. 


\section{HASIL DAN PEMBAHASAN}

Kepemimpinan Kepala Desa merupakan pimpinan penyelenggaraan pemerintah desa. berdasarkan kebijakan yang telah ditetapkan bersama Badan Permusyawaratan Desa (BPD). Jadi, Kepala Desa sebagai kepala pemerintahan bertanggung jawab atas terselenggaranya pemerintahan desa karena kepala desa yang memegang peran yaitu sebagai wakil rakyat yang terpilih dan dipilih secara langsung oleh masyarakat desa. Kepala Desa harus memiliki kemampuan, bakat, kecakapan, dan sifat kepemimpinan, disamping menjalankan kegiatan-kegiatan, koordinasi, fungsi, peran dan tanggung jawab.

Kepala desa tentunya wajib melibatkan masyarakat dalam setiap program pemerintahan. Bentuk kebijakannya adalah setiap program yang telah direncanakan wajib di sosialisasikan kepada masyarakat. Partisipasi masyarakat dalam pembangunan pada dasarnya merupakan suatu bentuk keterlibatan dan keikutsertaan masyarakat secara aktif dan sukarela dari dalam dirinya maupun dari luar dirinya dalam keseluruhan proses kegiatan yang bersangkutan dalam pembangunan desa.

Dalam penelitian ini, peneliti memfokuskan penelitian kepada teknik Kepemimpinan Kepala Desa Dalam Mewujudkan Desa Mandiri Di Desa Bojongmalaka Kecamatan Baleendah Kabupaten Bandung. Seperti yang diketahui tentang teknik adalah cara atau metode yang dipakai agar suatu proses kepemimpinan dapat mencapai keberhasilan tertentu. Seorang pemimpin mempunyai sifat, kebiasaan, tempramen, watak dan kepribadian sendiri yang unik, sehingga tingkah laku dan gayanya yang membedakan dirinya dengan orang lain. Gaya atau style hidup seorang pemimpin akan mewarnai perilaku.

Maka peneliti menggunakan teknik kepemimpinan yang dikemukakan Pamudji sebagai berikut : 
a. Teknik Pematangan atau Penyiapan Pengikut

- Pengarahan dan penerangan

b. Teknik Human Relation

- Pemberian motivasi

- Kebutuhan yang layak

- Pemberian kebutuhan akan rasa aman

c. Teknik Menjadi Teladan

- Memberikan teladan kedisplinan

- Memberikan contoh dalam pelaksanaan pekerjaan

d. Teknik Persuasi Dan Pemberian Perintah

- Kejelasan dalam memberikan perintah

e. Teknik Menggunakan Sistem Komunikasi Yang Cocok

- Komunikasi menggunakan bahasa yang sederhana

f. Teknik Penyediaan Fasilitas

- Kelengkapan fasilitas kerja

- Pemeliharaan fasilitas kerja

Berdasarkan penelitian yang telah dilakukan, bahwa keberhasilan dari kepemimpinan kepala desa dalam mewujudkan desa mandiri yaitu dengan menunjang dimensi beserta indikator tersebut berikut penjelasan nya.

a. Pematangan atau Penyiapan

Dalam teknik pematangan dan penyiapan pengikut dilakukan dengan mengadakan penerangan dan propaganda yang dimkasud dengan memberi penerangan adalah memberikan keterangan yang jelas dan benar kepada orang-orang. Sehingga mereka memperoleh pengertian yang sejelas-jelasnya mengenai masalah, adapun melakukan propaganda artinya mengajak dan mendorong kepada orang-orang atau memaksakan kehendak pemimpin kepada yang dipimpin dengan memberikan keterangan-keterangan yang benar bahkan juga tidak benar.

Teknik Pematangan dan Penyiapan Pengikut Pemimpin dalam pelaksanaan kepemimpinan harus berusaha melakukan pematangan 
dan penyiapan pengikut, agar para bawahan dapat mengikuti keinginan pemimpin di dalam proses tujuan organisasi. Pada dasarnya pematangan dan penyiapan pengikut dapat dilaksanakan melalui teknik penerangan maupun propaganda. Dalam teknik penerangan seorang pemimpin harus berusaha menerangkan maksudnya secara jelas dan benar kepada bawahan, sehingga mereka dapat memahami keinginan pemimpin dalam pencapaian tujuan organisasi. Agar berhasil dalam melaksanakan teknik penerangan, seorang pemimpin harus menggunakan bahasa yang mudah dimengerti baik lisan maupun tulisan. Kemudian materi yang digunakan harus obyektif dan menunjukan fakta yang sebenarnya.

Adanya pengarahan dan penerangan sesuai dilapangan yaitu hal-hal yang harus diperhatikan yaitu memberikan penerangan terhadap perangkat desa sebelumnya dengan cara diadakan penyelidikan untuk memperoleh pengetahuan pendidikan, adat istiadat dari orang yang akan diberikan penerangan dan pengarahan nantinya

b. Human Relation

Teknik human relation adalah rangkaian atau proses kegiatan memotivasi bawahan, melalui pemberian motivasi atau dorongan agar mau bergerak ke arah yang dikehendaki. Pada dasarnya setiap manusia apabila memasuki suatu organisasi, baik yang bersifat formal maupun non formal akan mempunyai motivasi yang baik terlepas bagaimana memenuhi kebutuhan hidupnya. Manusia sebagai mahluk hidup yang mempunyai kebutuhan hidup yang beraneka ragam baik kebutuhan yang bersifat material maupun kebutuhan psikologis.

1) Kebutuhan akan kelayakan

Seorang pemimpin harus berusaha memperlakukan para bawahannya sebagaimana layaknya manusia yang memiliki perasaan, pikiran, serta harga diri. Berkaitan dengan itu, maka 
seorang pemimpin harus berusaha memenuhi kebutuhan akan kelayakan bawahannya yang merupakan hak asasi manusia.

2) Kebutuhan akan penghargaan

Seorang pemimpin harus berusaha memberikan penghargaan kepada pegawai yang berprestasi, baik berupa ucapan selamat, piagam, tanda jasa ataupun lainnya, sehingga akan mendorong pegawai untuk lebih meningkatkan kinerjanya.

3) Kebutuhan akan keamanan dan ketentraman

Keamanan dan ketentraman merupakan dambaan setiap orang karena dapat menimbulkan kebahagiaan lahir dan batin. Seorang pemimpin harus memperhatikan kebutuhan keamanan, di antaranya keamanan jiwa dan raga, kesehatan, harta benda, keluarga dan keamanan dalam pelaksanaan. Melalui upaya ini diharapkan para pegawai dapat lebih bersemangat dalam melaksanakan kerjanya.

4) Kebutuhan untuk menjadi anggota dari suatu organisasi atau golongan

Setiap manusia akan menyadari bahwa ia tidak dapat memenuhi kebutuhan hidupnya oleh diri sendiri, sehingga mendorong manusia itu untuk hidup bermasyarakat dan berorganisasi, demi untuk dapat memenuhi kebutuhan hidupnya. Seorang pemimpin yang baik akan senantiasa memperhatikan kebutuhan tersebut, yaitu dengan mengikutsertakan pegawai dalam setiap pelaksanaan pekerjaan, sehingga akan terwujud suatu team work, disamping memberikan keleluasaan bagi para pegawai untuk menjadi anggota suatu organisasi lain di luar bidang tugasnya.

Berdasarkan hasil wawancara dengan Sekretaris Desa yaitu bapak Asep Deni jadi kepala desa memberikan motivasi kepada bawahannya untuk saling bekerjasama satu sama lain demi 
terlaksananya tujuan desa demi kepentingan bersama untuk semua masyarakat dengan memberi rasa aman juga kepada masyarakatnya. Kebutuhan akan kelayakan disini kepala desa memberi kebutuhan akan kelayakan kepada bawahannya dengan melihat potensi perangkat desa untuk memberikan kebutuhan dengan tidak semena-mena terhadap bawahan. Selain itu juga kebutuhan akan penghargaan diberikan oleh kepala desa terhadap pegawainya yang beprestasi dengan memberikan reward dan memberikan tanda jasa untuk mereka yang kinerja kerja nya bagus dan beprestasi sehingga dengan diadakan hal ini mendorong pegawainnya untuk lebih semangat lagi dalam bekerja. Selain itu juga kebutuhan akan rasa aman dan tentram diberikan kepada pegawainya seperti kesehatan dan jiwa raga ambil saja contoh ketika salah satu pegawai yang rumah nya terkena banjir kepala desa siap siaga memberi bantuan terhadap pegawai tersebut . Selain itu juga kepala desa itu memberi kebebasan dan kewenangan terhadap pegawainya untuk berorganisasi demi memenuhi kebutuhan hidupnya diluar bidang tugasnya yang terpenting mereka ada pada satu teamwork.

\section{c. Menjadi Teladan}

Teknik menjadi teladan merupakan teknik yang digunakan oleh pemimpin dalam menggerakan dan mempengaruhi bawahan. Dalam teknik ini seorang pemimpin berusaha menjadikan dirinya panutan atau teladan bagi orang lain, sehingga bawahan akan mengikuti keteladanan tersebut. Penteladanan atau pemberian contoh bagi seorang pemimpin merupakan suatu yang mutlak harus dilakukan, yaitu melalui aspek positif dalam bentuk anjuran dan aspek negatif dalam bentuk larangan. Apabila hal ini telah dilakukan maka para bawahan akan terpengaruh untuk mengikuti contoh yang diberikan oleh pemimpin.

Seorang pemimpin dalam rangka pemberian teladan harus dapat membatasi dan menguasai diri, khususnya tidak menyimpang 
atau melanggar larangan-larangan atau pantangan-pantangan dan sebaliknya selalu memenuhi anjuran-anjuran atau keharusankeharusan. Untuk melaksanakan semua itu diperlukan suatu disiplin yang kuat. Dengan demikian bawahan akan bersedia mengikuti pemimpin.

Tipikal Kepala Desa ini tipe orang yang suka bekerja dan saling membantu dalam setiap tugas perangkat desa bisa dilihat juga dari ada setiap program pembangunan infrastruktur kepala desa sering datang dan langsung terjun ke lapangan bersama masyarakat untuk saling membantu bisa kita ;lihat saat pembuatan jalan di desa ini telihat jelas bagaimana kepala desa bekerja sama. Jika dilihat dari pelaksanaan kerjanya kita bisa lihat jika dia sedang bekerja beliau tidak asal-asalan main tunjuk langsung, tapi beliau sudah mengerti dan paham akan tugas para pegawainya.

d. Persuasi dan Pemberian Perintah

Untuk mempengaruhi atau menggerakan para bawahan, seorang pemimpin harus mampu melakukan persuasi dan pemberian perintah dengan baik. Persuasi bertujuan bukan untuk memaksa, akan tetapi mempengaruhi sikap orang lain dengan cara halus tidak kasar atau dengan paksaan, sehingga dalam keadaan tertentu orangorang akan bertingkah laku sesuai dengan yang dikehendaki oleh orang yang melakukan persuasi, namun sesuai pula dengan keinginannya.

Sedangkan mengenai pemberian perintah dapat diartikan menyuruh orang lain untuk mematuhi dan melakukan sesuatu yang dalam pelaksanaannya mengandung adanya kekuasaan (power) dan kekuatan (force). Kekuasaan adalah wewenang (authority) dari yang memerintah ditambah dengan kemampuan untuk memaksakan perintah. Ketaatan perintah disebabkan karena wibawa pemimpin yang timbul dari kelebihan-kelebihan yang ada pada diri pemimpin, perintah menunjukan adanya hubungan antara atasan dengan bawahan. 
Kepala desa itu tidak menunjuk-nunjuk bawahannya dan tidak membeda-bedakan mana atasan mana bawahan dikarenakan mereka pun sudah ada tugas dan tanggungjawabnya masing-masing, namun kepala desa justru ingin bergotong royong jika melakukan sesuatu demi kepentingan bersama demi terciptanya kesejahteraan masyarakat

e. Penggunaan Sistem Komunikasi yang Cocok

Kegiatan seorang pemimpin dalam mengarahkan, membimbing, mempengaruhi pikiran, perasaan atau tingkah laku bawahan di dalam pencapaian tujuan organisasi tidak akan terlepas dari kegiatan komunikasi. Dengan demikian seorang pemimpin harus menguasai teknik komunikasi yang baik, sehingga setiap informasi atau pesan yang disampaikan dapat diterima dengan baik dan sebaliknya setiap informasi dari bawahan akan mudah diterima oleh pemimpin.

Komunikasi terbaik di dalam suatu organisasi adalah komunikasi dua arah, yaitu komunikasi timbal balik diantara pimpinan harus memperlihatkan faktor-faktor sebagai berikut:

a. Bahasa yang digunakan.

b. Dasar pendidikan dari komunikasi.

c. Perbedaan latar belakang kehidupan sosial bawahan.

d. Perbedaan kedudukan pimpinan.

e. Alat atau media yang digunakan.

Kepemimpinan kepala desa sekarang itu memiliki banyak perubahan bisa dilihat dari pembangunan infrastruktur masyarakat jika akan dilakukan penyuluhan maka di desa suka ada penyuluhanpenyuluhan yang biasa didatangi warga. jadi komunikasi antara kepala kades dengan masyarakat ini sangat bersinergis satu sama lain

f. Penyediaan fasilitas-fasilitas

Apabila sekelompok orang sudah siap untuk, mengikuti ajakan si pemimpin, maka orang-orang tersebut harus diberi fasilitas- 
fasilitas atau kemudahan-kemudahan. Beberapa fasilitas atau kemudahan tersebut meliputi sebagai berikut :

1) Kecakapan, yang dapat diberikan melalui pendidikan dan latihan.

2) Uang, biasanya disediakan dalam anggaran belanja.

3) Perlengkapan dan tempat kerja, biasanya dengan uang dapat diperoleh barang-barang perlengkapan dengan cara membeli, atau menyewa tempat kerja.

4) Waktu, mutlak diperlukan untuk melakukan sesuatu walaupun tersedia fasilitas-fasilitas lainnya, sedangkan waktu selalu terbatas.

5) Perangsang, adalah sesuatu yang menarik sehingga menimbulkan kegairahan atau keinginan untuk memilikinya atau mendapatkannya.

Demikianlah beberapa teknik-teknik kepemimpinan yang penting yang dapat menggerakkan orang-orang. Teknik-teknik lain mungkin dapat dipergunakan, terutama dalam hubungan dengan situasi dan kondisi tertentu berdasarakan hasil wawancara dengan sekretaris desa bapak Asep mengatakan bahwa fasilitas yang ada didesa sekarang sudah lengkap dikarenakan yang dulunya desa ini desa berkembang atau tradisonal sekarang desa ini akan menuju desa mandiri dengan terpilihnya desa ini menjadi salah satu desa terbaik di Kecamatan Baleendah Kabupaten Bandung dengan kelengkapan berbasis modern.

Bahwa fasilitas yang ada didesa sekarang sudah lengkap dikarenakan yang dulunya desa ini desa berkembang atau tradisonal sekarang desa ini akan menuju desa mandiri dengan terpilihnya desa ini menjadi salah satu desa terbaik di Kecamatan Baleendah Kabupaten Bandung dengan kelengkapan berbasis modern.

\section{KESIMPULAN}

Berdasarkan penelitian yang telah dilakukan, dalam memimpin desa pemimpin memiliki pengaruh cukup kuat untuk pembangunan desa. Baik masuknya program pemerintahan desa atau sampai selesai pelaksanaan 
pembangunan. Pemerintahan yang paling dekat dengan desa adalah kepala desa bahwa kepemimpinan kepala desa sangat berpengaruh terhadap jalannya roda pemerintahan karena segala keputusan ada ditangan kepala desa itu sendiri oleh sebab itu kepala desa sangat berperan penting di masyarakat.

Bahwa keberhasilan dari Kepemimpinan Kepala Desa Dalam Mewujudkan Desa Mandiri Di Desa Bojongmalaka Kecamatan Baleendah maka peneliti mengambil kesimpulan sebagai berikut :

a. Pematangan atau Penyiapan

Adanya pengarahan dan penerangan sesuai dilapangan yaitu hal-hal yang harus diperhatikan yaitu memberikan penerangan terhadap perangkat desa sebelumnya dengan cara diadakan penyelidikan untuk memperoleh pengetahuan pendidikan, adat istiadat dari orang yang akan diberikan penerangan dan pengarahan nantinya

\section{b. Human Relation}

Memberikan motivasi kepada bawahannya untuk saling bekerjasama satu sama lain demi terlaksananya tujuan desa demi kepentingan bersama untuk semua masyarakat dengan memberi rasa aman juga kepada masyarakatnya. Kebutuhan akan kelayakan disini kepala desa memberi kebutuhan akan kelayakan kepada bawahannya dengan melihat potensi perangkat desa untuk memberikan kebutuhan dengan tidak semena-mena terhadap bawahan

c. Menjadi Teladan

Tipikal Kepala Desa ini tipe orang yang suka bekerja dan saling membantu dalam setiap tugas perangkat desa bisa dilihat juga dari ada setiap program pembangunan infrastruktur kepala desa sering datang dan langsung terjun ke lapangan bersama masyarakat untuk saling membantu bisa kita ;lihat saat pembuatan jalan di desa ini telihat jelas bagaimana kepala desa bekerja sama. Jika dilihat dari pelaksanaan kerjanya kita bisa lihat jika dia sedang bekerja beliau tidak asal-asalan 
main tunjuk langsung, tapi beliau sudah mengerti dan paham akan tugas para pegawainya.

d. Persuasi dan Pemberian Perintah

Kepala desa itu tidak menunjuk-nunjuk bawahannya dan tidak membeda-bedakan mana atasan mana bawahan dikarenakan mereka pun sudah ada tugas dan tanggungjawabnya masing-masing, namun kepala desa justru ingin bergotong royong jika melakukan sesuatu demi kepentingan bersama demi terciptanya kesejahteraan masyarakat

e. Penggunaan Sistem Komunikasi yang Cocok

Kepemimpinan kepala desa sekarang itu memiliki banyak perubahan bisa dilihat dari pembangunan infrastruktur masyarakat jika akan dilakukan penyuluhan maka di desa suka ada penyuluhan-penyuluhan yang biasa didatangi warga. jadi komunikasi antara kepala kades dengan masyarakat ini sangat bersinergis satu sama lain

f. Penyediaan fasilitas-fasilitas

Bahwa fasilitas yang ada didesa sekarang sudah lengkap dikarenakan yang dulunya desa ini desa berkembang atau tradisonal sekarang desa ini akan menuju desa mandiri dengan terpilihnya desa ini menjadi salah satu desa terbaik di Kecamatan Baleendah Kabupaten Bandung dengan kelengkapan berbasis modern.

Berdasarkan penelitian yang telah dilakukan, dalam memimpin desa pemimpin memiliki pengaruh cukup kuat untuk pembangunan desa. Baik masuknya program pemerintahan desa atau sampai selesai pelaksanaan pembangunan. Pemerintahan yang paling dekat dengan desa adalah kepala desa bahwa kepemimpinan kepala desa sangat berpengaruh terhadap jalannya roda pemerintahan karena segala keputusan ada ditangan kepala desa itu sendiri oleh sebab itu kepala desa sangat berperan penting di masyarakat.

Bahwa keberhasilan dari Kepemimpinan Kepala Desa Dalam Mewujudkan Desa Mandiri Di Desa Bojongmalaka Kecamatan Baleendah maka peneliti mengambil kesimpulan sebagai berikut : 
Kepemimpinan kepala desa Bojongmakala Kabupaten Bandung dirasa sudah sangat memenuhi kriteria kepemimpinan menurut teori yang di gunakan dalam penelitian ini. Kepala desa disini memberikan penerangan terhadap perangkat desa sebelumnya. Kepala desa selalu memberikan motivasi kepada bawahannya untuk saling bekerja sama. Kepala desa ini tipe yang suka bekerja dan saling membantu dalam setiap petugas perangkat desa. kepala desa tidak dengan seenaknya menunjuk-nunjuk bawahannya. Menyediakan fasilitas desa yang kian lengkap.

Maka disini, penulis merekomendasikan bahwa sosok kepemimpinan kepala desa ini sudah cukup bagus kalau bisa tetap dipertahankan sehingga akan menjadi desa mandiri nantinya

\section{DAFTAR PUSTAKA}

\section{Buku}

Pamudji , 2003. Kepemimpinan Pemerintahan di Indonesia. Jakarta : Bumi Aksara .

Sanusi , Achmad dkk 2009 . Kepemimpinan Sekarang Dan Masa Depan. Bandung : Prospect Bandung.

Hasibuan, Stonner, 2003. Manajemen Sumber Daya Manusia, Edisi Revisi, Jakarta : PT. Bumi Aksara.

Safaria , Wahjosumidjo 2004. Kepemimpinan Indonesia. Yogyakarta : Graha Ilmu.

Syafi'ie, Inu Kencana 2003. Kepemimpinan Pemerintahan di Indonesia. Bandung: PT Radika Aditama .

Yansen. 2014. Revolusi Dari Desa. Jakarta: PT. Elex Media Kompetindo. Yulk Gary. 2009. Kepemimpinan Dalam Organisasi. Jakarta: Index.

Moch, Solekhan, 2012, Penyelenggaraan Pemerintahan Desa.. Malang : Setara 
Tampubolon , 2007. Pemimpin dan Kepemimpinan Dalam Manajemen. Jakarta : PT. Rineka Cipta.

Siagian, P. Sondang. 2007. Teori dan Praktek Kepemimpinan. Jakarta: Rineka Cipta.

Sanusi. Ahmad, dan Sobary Sutikno. 2009. Kepemimpinan Sekarang dan Masa Depan. Bandung: Penerbit Prospect

Ndraha, Talizuduhu. 2003. Kybernology (Ilmu Pemerintahan Baru I). Jakarta: PT.Rineka Cipta.

Kartohadikoesomo , 2007, Pedoman Penyelenggaraan Pemerintahan Desa, Fokusmedia.

Edi, Nurcholis 2011. Membangun Masyarakat Memberdayakan Rakyat. Bandung : Refika Aditama.

Ordway Tead, 2010, Kepemimpinan Dalam Perusahaan. Jakarta : Bumi Aksara .

Moleong, J. Lexy, 2011. Metodologi Penelitian Kualitatif Edisi Revisi. Bandung: Rosda Karya

Sutikno. 2004. Otonomi Desa. Jakarta : PT. Raja Grafindo Persada.

Northouse, Peter G. 2013. Kepemimpinan Teori dan Praktik. Jakarta: PT. Indeks.

\section{Dokumen :}

Undang-Undang Nomor 23 Tahun 2014 Tentang Desa.

Undang-Undang Nomor 6 Tahun 2014 Tentang Pemerintahan Desa.

Direktorat Jenderal Pembangunan dan Pemberdayaan Masyarakat Desa Kementerian Desa Pembangunan Daerah Tertinggal dan Transmigrasi Republik Indonesia. 